Macmillan Professional Masters

Employee Relations 
Macmillan Professional Masters

Titles in the series

Company Accounts Roger Oldcorn

Constitutional and Administrative Law John Alder

Contract Law Ewan McKendrick

Cost and Management Accounting Roger Hussey

Criminal Law Marise Cremona

Data Processing John Bingham

Employee Relations Chris Brewster

Land Law Kate Green

Landlord and Tenant Law Godfrey Cole and Margaret Wilkie

Management Roger Oldcorn

Marketing Robert G. I. Maxwell

Office Administration E. C. Eyre

Personnel Management Margaret Attwood

Study Skills Kate Williams

Supervision Mike Savedra and John Hawthorn 


\section{Employee Relations}

\section{Chris Brewster}

Senior Lecturer in Industrial Relations

Cranfield School of Management 


\section{(C) Chris Brewster 1984, 1989}

All rights reserved. No reproduction, copy or transmission of this publication may be made without written permission.

No paragraph of this publication may be reproduced, copied or transmitted save with written permission or in accordance with the provisions of the Copyright Act 1956 (as amended), or under the terms of any licence permitting limited copying issued by the Copyright Licensing Agency, 33-4 Alfred Place, London WC1E 7DP.

Any person who does any unauthorised act in relation to this publication may be liable to criminal prosecution and civil claim for damages.

First published in 1984 by Pan Books Ltd as Understanding Industrial Relations in the Breakthrough series.

Fully revised and updated edition first published in 1989 by MACMILLAN EDUCATION LTD

Houndmills, Basingstoke, Hampshire RG21 2XS

and London

Companies and representatives

throughout the world

British Library Cataloguing in Publication Data

Brewster, Chris

Employee relations.

Fully rev. and updated

ed.

(Macmillan professional masters)

1. Great Britain. Industrial relations

I. Title II. Understanding industrial

relations

$331^{1} .0941$

ISBN 978-0-333-48783-9

ISBN 978-1-349-20139-6 (eBook)

DOI 10.1007/978-1-349-20139-6 


\section{Contents}

Preface

vii

1 What is employee relations?

1.1 Fact or opinion?

1.2 One definition

1.3 Work in Britain

1.4 The contract of employment

1.5 Is employee relations important? 8

1.6 Where work occurs 14

$\begin{array}{lll}1.7 & \text { Changes in work } & 17\end{array}$

2 Management 19

2.1 Managers or owners? 20

2.2 Managerial objectives 22

2.3 Management and employee relations 22

2.4 Differences within management 24

2.5 Departments, levels and employee relations 30

2.6 Employers' associations 30

2.7 Managers as employees $\quad 33$

2.8 Management: in summary 34

3 The trade unions 35

3.1 The trade union member 36

3.2 The employee representative 41

3.3 Union structure 45

3.4 The spice of life 50

3.5 'Feds' and 'confeds' 51

3.6 The Trades Union Congress 51

4 Employee relations and the state 53

4.1 The state as employer 54

4.2 The state as economic manager 57

4.3 The state as law-giver $\quad 64$

4.4 The state as provider of specialist services 67

5 The law and collective bargaining 69

5.1 The sources of the law 69

5.2 Industrial tribunals 70

$\begin{array}{ll}5.3 \text { Codes of practice } & 70\end{array}$

5.4 Voluntarism and the law 72 
$\begin{array}{lll}\text { 5.5 The status of trade unions } & 72\end{array}$

$\begin{array}{lll}5.6 & \text { Strikes } & 75\end{array}$

$\begin{array}{lll}5.7 & \text { Collective agreements } & 78\end{array}$

5.8 The changing face of employment law 80

6 Individuals and employment law $\quad 82$

$\begin{array}{lll}6.1 & \text { Before joining } & 82\end{array}$

$\begin{array}{lll}6.2 \text { On joining } & 84\end{array}$

6.3 The law during employment 88

6.4 Termination of the contract 96

7 Workplace employee relations $\quad 102$

$\begin{array}{lll}7.1 & \text { The variety of workplaces } & 102\end{array}$

$\begin{array}{lll}7.2 & \text { Employee relations in context } & 102\end{array}$

$\begin{array}{lll}7.3 & \text { Coordination and control } & 104\end{array}$

$\begin{array}{lll}7.4 & \text { The rules } & 104\end{array}$

$\begin{array}{lll}7.5 & \text { Procedures } & 108\end{array}$

$\begin{array}{lll}7.6 & \text { Non-union methods } & 116\end{array}$

$\begin{array}{lll}7.7 & \text { Summary } & 117\end{array}$

8 Negotiating $\quad 119$

8.1 What is 'negotiating'? 119

$\begin{array}{lll}8.2 & \text { Industrial relations negotiations } & 121\end{array}$

$\begin{array}{ll}\text { 8.3 The power position } & 124\end{array}$

$\begin{array}{lll}8.4 & \text { The bargaining range } & 126\end{array}$

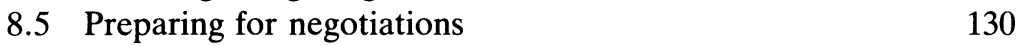

$\begin{array}{lll}\text { 8.6 The stages of negotiation } & 134\end{array}$

$\begin{array}{lll}8.7 \text { Tactics in negotiations } & 140\end{array}$

9 Management policies $\quad 146$

9.1 Trends - the small scale 146

$\begin{array}{ll}\text { 9.2 Managing employee relations } & 147\end{array}$

$\begin{array}{lll}9.3 & \text { Employee relations policies } & 147\end{array}$

$\begin{array}{lll}9.4 & \text { Employee relations objectives } & 149\end{array}$

$\begin{array}{ll}\text { 9.5 Developing the policies } & 157\end{array}$

$\begin{array}{lr}\text { Glossary of Terms } & 160\end{array}$

$\begin{array}{lr}\text { Further Reading } & 165\end{array}$

$\begin{array}{lr}\text { Answer Section } & 167\end{array}$

$\begin{array}{lr}\text { Index } & 174\end{array}$ 
There can be few subjects which receive as much attention as employee relations, or industrial relations as it is often called. It is constantly in the newspapers and on television; it is the source of countless pub discussions.

The first version of this book was called Understanding Industrial Relations. The title change - to Employee Relations - helps to distinguish this book, which has been significantly updated, from that one - and also reflects an important change that occurred in the 1980s. At the beginning of the decade trade unions were powerful and confident; it was generally considered that most issues in most workplaces would involve a trade union presence. By the end of the decade the unions were under pressure and on the defensive; the general wisdom now is that in many workplaces relationships between managers and employees will only occasionally, if ever, involve the unions. In practice, not all that much may have changed; and the structure of this book at least remains the same. The title change does, however, emphasise the wide scope of the subject matter.

This book then will generally use the words 'employee relations' and 'industrial relations' interchangeably, though more often utilising the former. Whatever we call it, the fact remains that for many of us our knowledge of the subject matter is somewhat scanty.

Often this may not matter too much-lack of knowledge rarely prevents people having an opinion! For two groups, however, such ignorance can be crucial: Employee Relations provides some basic facts and raises some of the central issues specifically for these groups.

There are, first, practitioners. These include managers - in industry, in commerce, in the public sector, in large and small organisations. A central part of their task involves managing their relationship with their subordinates, though often they have little training in or experience of employee relations. This practitioner category also includes union representatives.

Second, there are those who are about to face up to employee relations in the UK: students who are completing their courses and hoping to get a job, people moving into jobs with greater industrial relations responsibilities and managers from abroad coming to this country for the first time. This book will help them all to understand employee relations. 
It is of course a contentious and value-laden subject. That is what makes it so fascinating. Facts about employee relations may be neutral but the way they are presented can vary. I have set out to challenge opinions - not to get you to change your mind, but to make you clearer about the basis of your opinion. In order to do so I have tried to make the book easy to read and to convey the excitement of the subject. Perhaps where it falls short of these targets you could take it as a challenge!

Whilst I have tried to write simply and clearly I have tried to remain analytical. This is not a schoolboy text. It requires, at least, an intelligent appreciation of the daily news and, at best, experience within employing organisations.

The first chapter of the book examines the subject of employee relations in general, and the next three consider the main parties involved: the management, the unions and the state. Chapters 5 and 6 examine the legal framework, and the following three chapters examine employee relations practice in employing organisations. 


\section{Acknowledgements}

This is an update of a book first published in 1984. It would be impossible to acknowledge all the help I have had in writing and amending this book. I learnt a lot from the great number of managers and union officials who have taken part in the training programmes I have run. I would like to thank by name: Sarah Atterbury who typed the manuscript and kept me organised; Lynn and Rebecca and Tom who kept it all in perspective. 